\title{
GORRIGENDUM
}

\section{PARALLELS AND CONTRASTS IN GENDERED HISTORIES OF INDUSTRIAL LABOUR IN BURSA AND BOMBAY $185^{\circ-1910-}$ CORRI GENDUM}

\author{
HAT I CE Y I L D I Z \\ University of Cambridge
}

doi:10.1017/Soo18246X16000340. Published by Cambridge University Press, 8 November 2016.

In this article:-

1) The word 'daily' should read 'monthly' at the head of the table on the seventeenth page of the article.

2) The sentence in row 12 on the sixteenth page of the article should read: 'as opposed to seven rupees per month in the mills'.

R E F E R E N C E

Yildiz, Hatice 'Parallels and contrasts in gendered histories of industrial labour in Bursa and Bombay 185o-1910', Historical Journal, doi:10.1017/Soo $18246 X_{1} 6000340$. 